\title{
印刷インキ基礎講座 (最終講)
}

（色材，61 [6]353-358. 1988)

機 能 性 イン キ

\section{1. は じめに}

印刷インキは，この講座の第 1 講に紹介されているよ 亏に, 印刷方式あるいは版式, 乾燥方式, インキ組成, 被印刷体，用途，インキ皮膜特性なぞにより分類され る。これらの分類の中にあって機能性インキとは従来特 殊インキと呼ばれるインキの範ちゅうに分類されてい た。

印刷インキは元来文字や図柄を複製するために使用さ れてきたものであるが，今日一部の印刷インキにはその 目的だけに止まらず，求められる役割も多様化し被印刷 物に特殊機能が要求されるよらになってきた。機能性イ ンキの中には数十年前に開発され今日に至っている製品 もあれば，新たにその機能が見直され用途開発が進めら れている製品も多い。

本報では特殊機能を持った印刷インキについて取上げ てみたい。

\section{2. 磁性インキ}

キャッシュカード，クレジットカード，プリペイドカ 一ドなどのカード類, 自動改札用切符, 航空機搭乗券, 定期券など磁性膜を備えた製品が普及している。これら の製品は磁気テープを貼ったり，裏面がグラビア方式に より全面コートされたものであるが，最近，高速道路磁 気通行券やバスの回数券など印刷機によりストライプ状 に磁性膜が印刷された製品が多く見られるようになって きた。今迄磁性インキといらと MICR (Magnetic Ink Character Recognition) 用に使われるインキととら兄 られていたが，磁気記録媒体としての機能が利用される ようになってきている。

磁性インキは，ビヒクル中に磁性粉が分散されたイン

昭和 63. 4.14 受理

Functional Inks

Hiroshi Gото

* 東京インキ株式会社

東京都北区田端新町 2-7-15（宁114）
後藤 博 史*

キで $\gamma-\mathrm{Fe}_{2} \mathrm{O}_{3}, \mathrm{Fe}_{3} \mathrm{O}_{4}, \mathrm{Ba}$ エ ライトなどの磁性粉が主 に使われる。

MICR 用磁性インキは小切手や手形の一部に磁性イ ンキ文字や記号を印刷するのに使用され，その文字や記 号は人間の眼で判読でき, 且つその磁気特性により電算 機入力の際に機械的読み取りを可能にする。この MICR に使用される文字や記号には米国銀行協会が採用してい る E-13 B 型と欧州 ECMA が開発した CMC-7 型があ り，日本では E-13 B 型が広く普及している。 JIS X 9002 に (E 13 B) 磁気インキ文字読取用字体, および印 字仕様が規格されて和り, 使用される磁気インキ文字や 記号はストロークと呼ばれ 10 個の数字と 4 個の特殊記 号から成り立っている。印刷されたストロークは電圧波 形のピークの位置と振幅で判別される。

MICR の印刷は凸版や平版方式による枚葉印刷が主 流であったが，印刷業界の省力化，スピードアップの面 から印刷方式もフォーム輪転に移行が進み, 同時にイン キも酸化重合型インキから紫外線硬化型インキに変わっ てきている。

\section{OCR 用インキ}

OCR とは Optical Character Recognition（光学的文 字認識) の略で, 一般的には Optical Character Reader (光学文字読取装置) の意味をも含めて OCR と呼ば れている。

コンピュータへの情報入力のため, 印刷された活字や 手書きの文字をキーパンチやテープパンチのよらな手段 を経ずに直接, 光学的に読み取りを行う OCR スキャナ

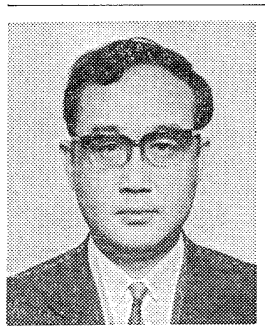

[氏名]ごとう ひろし

[現職]東京インキ株式会社, 平 版インキ生産本部技術部

[趣味】園芸 〔経歴〕昭和 40 年 学習院大学卒, 同年東京インキに 入社現在に至る。 


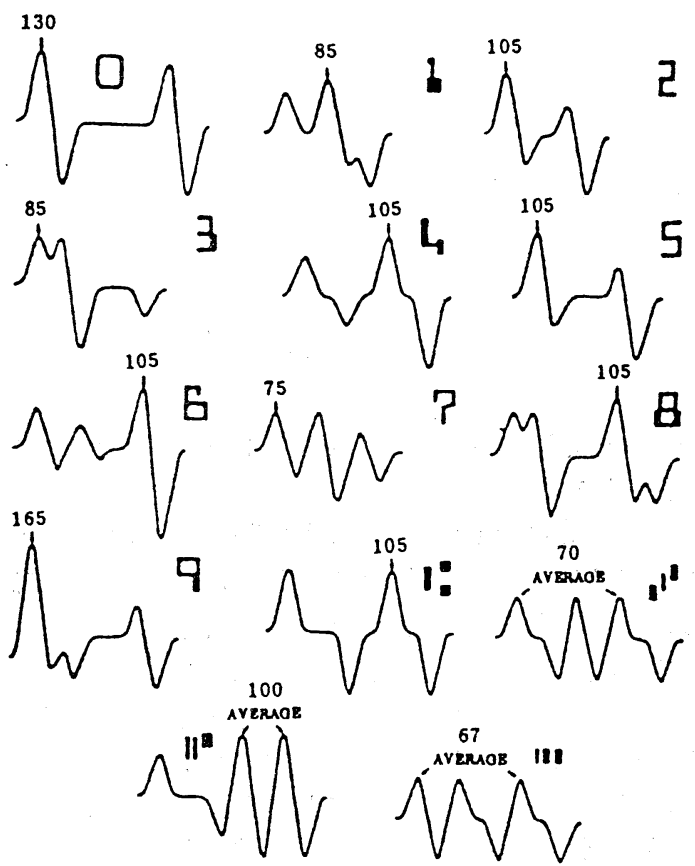

図-1 IDEAL WAVEFORMS E.13 B

用に規格化された伝票を印刷するために使用される印刷 インキである。

OCR 伝票には文字の記載場所の 枠や記号をつける場 所や位置の指定など人間の眼で判読しらる印刷がなされ ている。これら印刷部に使用されるインキは，ドロップ アウトカラーと呼ばれンンピュータ入力の際に読み取り 装置が伝票の必要データを読み取る段階では処理の邪魔 になってはならない。すなわち, 読み取り装置に感して はならない。

一方, タイミングマークや記入文字は可読部であり, 一枚の伝票上に光学的に相反する特性の印刷が要求され る。これら非読部と可読部の印刷濃度の判定は PCS 值 (Print Contrast Signal) で管理される。

$$
\operatorname{PCS} \text { 值 }=\frac{\text { 用紙の反射率一印刷物の反射率 }}{\text { 用紙の反射率 }}
$$

従って, ドロップアウトカラーとしての印刷は出来る だけその反射率が紙の反射率に近いことが望ましく，逆 に可読部は反射率を低く, PCS 值が十分大きいことが 望まれる。OCR の読み取り装置は伝票を照射する光源 と反射光を受ける受光素子からなり, 可視領域と近赤外 領域で測定管理する二方式がある。

官庁が行う調查伝票, 収納業務伝票を始め, 郵便葉書 など, また流通業界では売上伝票, 売掛伝票, 受注伝票 などに利用され，電力，ガス，水道などのメータ検針を
上葉紙 (A) 50000000000000000 一プセル層 中葉紙 (B) 下葉紙 (C)
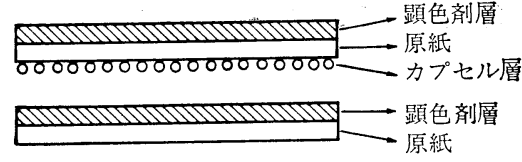

図-2 ノンカーボン減圧複写紙の構成

始めとする料金調定業務には古くから利用されてきた。

\section{4. ホワイトカーボンインキと減感インキ}

複写伝票として使用されているノンカーボン感圧複写 紙は，図-2 の通り三種類の加工紙から成り立っている。 カプセル層には感圧色素がゼラチンでマイクロカプセル 化され紙の裏面塗布されている。これに利用される色 素は主にフルオラン系とフタリド系色素で，この他フェ ノチアジン系, スピロラン系，ロイコトリフェニルメタ ン系色素る利用される。これらの色素はほぼ無色である が箻圧あるいはタイプ压によりマイクロカプセルが破壊 され，中，下葉紙上の顕色剂と接触反応して発色する。 顕色剂としては活性白土, サリチル酸金属塩, フェノー ル系樹脂化合物が使用される。

一般にノンカーボン複写紙の原紙のカプセル層, 並び に顕色剤層はェアナイフコーターなどにより全面塗布さ れているので上葉紙上に記入した記録は，中，下葉紙上 に複写される。しかしながら，特殊な伝票で，たとえば 下葉紙には同じ記録が必要だが中葉紙には部分的に記録 が不必要なことがある。その場合, 複写不要の部分のみ 発色を抑える必要性が生じる。

その部分の複写を阻止する方法として

（1）複写の必要部分にのみ顕色剂インキを印刷する 方法

顕色剤を含んだ印刷インキを伝票の必要部分にのみス ポット印刷する。普通, フレキソ印刷で行われ，これに 使用される顕色剂を含んだインキがホワイトカーボンイ ンキである。使用する用紙は顕色剂が塗布されていない ものを使用する。

（2）減感インキを印刷する方法

色素はカプセル破壞により顕色剂と反応し発色する。 従って，その反応を阻止するために，電子供与性のグリ コール化合物, カチオン活性剤の四級アンモニウム塩な どを含有したインキを複写不要部分の顕色剂層上に印刷 する。このインキは減感インキと呼ばれ顕色剂の求電子 反応性を和さ兄，色素の発色を止めることができる。 


\section{5. レジストインキ}

日本の電子産業の発展は目覚しく, 今や電子機器生産 国の中心的存在となっている。これら電子機器の生産增 に比例してプリント配線板の生産額も年々増加してい る。レジストインキとは処理をしたくない部分に，あら かじめ所定のパターンを印刷し，その部分に耐性をもっ た皮膜を形成する機能をもったインキのことで，プリン 卜配線板の製造過程に和いて多量飞使用されている。使 用する用途により，エッチング，メッキ，ソルダーの各 レジストインキに分類される。

プリント配線板は大きく分けて民性用配線板と産業用 配線板に分けられる。使用されるレジストインキも民生 用には，以前は加熱硬化型インキが主流であったが，高 生産性, 省エネルギー，無公害などの理由により紫外線 硬化型インキに変ってきている。一方, 産業用には加熱 硬化型インキが現在でも主流をなしている。

\section{1 エッチングレジスト}

エッチングレジストにはインキやドライフィルムのよ らな有機レジストとはんだメッキに代表される金属レジ ストがある。エッチングレジストインキは文字通りエッ チシグに耐兄得る耐酸性のビヒクルが皮膜形成要素とな って扣り，インキの乾燥方式により加熱乾燥型インキと 紫外線硬化型インキの二種類がある。

加熱乾燥型インキはアルカリ剥離の場合, 酸価の高い ロジン変性マレイン酸樹脂やアルコール可溶性フェノー ル樹脂がビヒクルに使用され，トリクレンなど溶剂剥離 の場合，ビニルポリマーやゴム系樹脂が用いられる。

インキを使用する銅張り積層板のエッヂングによるプ リント配線板の回路の作成工程（図-3）は，まず積層板 の銅表面にエッチングレジストインキで回路パターンを 印刷し，次にインキを乾燥してからエッチング郕で回路 パターン以外の銅䈃を取り除く。その後、レジスト皮膜 をアルカリ溶液, または溶剤により除去し回路は完成さ れる。エッチング剤としては塩化第二銅, 塩化第二鉄, スルカ江, 過硫酸塩, 硫酸・過酸化水素など数種類の土 ッチシグ薬剤がある。

エッチングレジストはプリント配線板の製造以外飞も ネームプレートなどのエッチングにも使用され，基材と しては，銅を始めとし鉄，ステンレススチール，黄銅， アルミニウム,ガラス,シリコンウェ八などがある。印 刷はスクリーン印刷が一般的である。

\section{2 メッキレジスト}

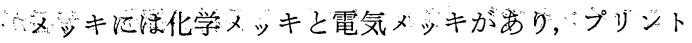

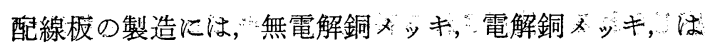

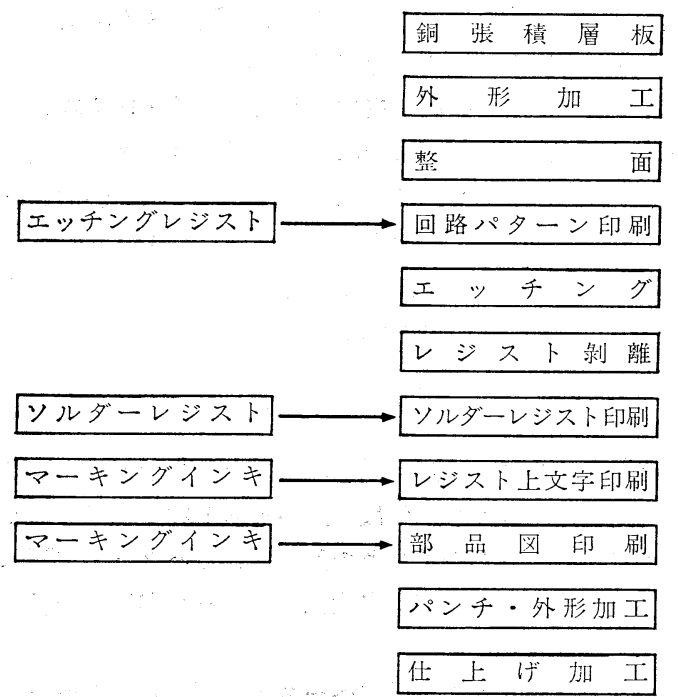

図-3＼cjkstart片面プリント配線板の製造工程

えだメッキ，金メッキなどの工程がある。無電解銅メッ キはプリント配線板のスルーホールメッキとして使用さ れ，その機能は，次工程の電気銅メッキのためにスルー ホール内に導電性を与える銅を析出させることである。 最近では高速厚付け無電解銅メッキが出現している。は んだメッキはプリント配線板の 金属エッチングレジス ト，部品リードのはんだ付けを良くする目的で使用され る。これらメッキ工程に扮いて, メッキ不要部分に印刷 されるインキがレジストイインキである。

\section{3 ソルダーレジスト}

ソルダーレジストインキは回路パターンが完成したプ リント配線板に印刷するインキで，その最大の役割は配 線板に電子部品をはんだで固定ずる際のはんだブリッジ の防止である。現在, はんだ付けの多くは溶融はんだを 噴流させるフロー式自動はんだ付将が主流で，ソルダー レジストが使われていないと配線間のショートが発生し やすくなる。その他りルダーレジストの役割は，回路の 腐蝕防止，ごみ付着あるいは湿気による絶縁低下の防 止，不必要な部分へのはんだの付着防止，はんだ槽の銅 泣るる污染防止，はんだ付け時の基板の熱ショック減少 などの機能がある。

ソルダーレジストインキに恃銅簿面に直接印刷するも のははんだメッキなどメッキ面に印刷するるの、フレキ シブル基板に用いるものなどがある。印刷方式はスクリ

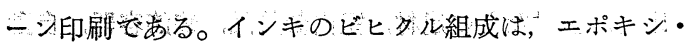
メラミン樹脂, エポキシ・尿素樹脂, ナルキッド・メラ

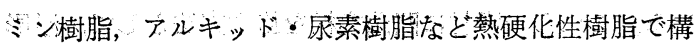
成されるもの、エポキシ・イミダタール誘導体などェポ 
キシ樹脂を主体とするもの，アクリル酸エステル類を光 重合させる紫外線硬化型などがある。

従来はメラミン樹脂を主体としたソルダーレジストが 主流であったが，このものは縮合反応でホルマリンを副 生するためメラミン樹脂系は衰退の一途をたどってい る。現在, 産業用配線板の分野ではエポキシ樹脂系が, また民生用配線板の分野では紫外線硬化型ソルダーレジ ストが目ざましい伸びを示している。

\section{6. 導電性インキ}

導電性インキとは金, 銀, 銅, カーボンなど導電性の 金属粉末をビヒクルに分散し，ペースト状に加工したイ ンキのことで，このインキで印刷されたパターン皮膜は 導電体を形成する。印刷方式はスクリーン印刷が一般的 である。

この導電性インキは通常ペーストと呼ばれ, 金ペース ト, 銀ペースト, 銅ペースト, カーボンペーストなどが 実用化されて扣り, 印刷回路, 電極, メッキ下地, ジャ ンパー配線, キーボード用接点, 印刷抵抗などの用途に 使用される。

\section{1 金ペースト}

金粉は化学的に安定で高導電性を示すが高価なため厚 膜 ICなど限られた用途に使用される。

\section{2 銀ペースト}

銀ペーストには高純度の銀の微粒子が使われる。銀粉 は導電性が良好でマイグレーションに難点があるが, 現 状, 比抵抗む $10^{-4} \sim 10^{-5} \Omega^{-} \mathrm{cm}$ 程度でジャンパ配線用 としては最も信頼性が高い。

\section{3 銅ペースト}

銀に比べて安価であるが粒子表面が酸化されやすく， 比抵抗も銀ペーストより高く $10^{-2} \sim 10^{-3} \Omega^{-} \mathrm{cm}$ で銀に 比べてその信頼性が落ちる。

\section{4 カーボンペースト}

カーボンペーストは使用するカーボン（ケッチェンブ ラック, アセチレンブラック, ファーネスブラック, グ ラファイトなど）の種類によって，その導電特性が大き く影響されるが，銀や銅ペーストに比較して比抵抗は高 い。デジタル回路に拈ける接点，抵抗值を問題としない 印刷回路，印刷抵抗などに利用されている。

\section{7. 発泡インキ}

床材, 壁材などの建材, 室内装飾品, 装飾容器, 自動 車の内張りなど凹凸模様の付いた素材が多く使用されて いる。これらの素材に凹凸模様を施す方法として, 浮彫 り状に所定の模様を刻み付けたェンボスロールやプレー
トに機械的に熱圧着して模様を付けるメカニカルエンボ ス法と発泡インキ，あるいは発泡抑制インキとの組合せ で化学的に凹凸模様を付けるケミカルエンボス法があ る。

発泡インキはビヒクル中に発泡剂を含有したインキ で, その分解温度や分解速度を調節するため, 尿素, 無 機塩, 酸, 金属石鹼などの分解促進化助剤が併用され る。

使用される発泡剤には有機発泡剂と無機発泡剤がある が，特殊用途を除いて現状ではアゾ系，ニトロソ系，ス ルホニルヒドラジド系の有機化合物が主に利用されてい る。これらの発泡剂は微粒子状態でビヒクル中に分散さ れるが，特殊な発泡剂として低沸点の気化性化合物を高 分子の款でくるんだ熱可塑性マイクロカプセルがある。

\section{1 発泡インキの使われ方}

印刷方式はグラビア，あるいはスクリーン印刷で行わ れる。

（a） 発泡インキが単独で使用される場合

被印刷体に直接文字や絵柄を印刷し, その後, 熱風炉 または赤外線で所定の温度に加熱すると発泡剤が分解し ガスが発生する。このガスによりインキ皮膜が膨脹し立 体模様が形成される。その際, 立体模様を必要としない 部分には必要に応じて通常の無発泡性のインキを使用す ることが出来る。

（b） 発泡抑制インキと併用される場合

発泡抑制インキとは印刷または塗布された発泡インキ の発泡工程以前にその皮膜の上層または下層に印刷する ことにより，その印刷部分の発泡インキの発泡を抑制す る機能をもったインキである。発泡抑制インキ中の抑制 剂が発泡インキ皮膜に移行して, 発泡剂あるいは発泡助 阂に作用し発泡温度を高めたり，発泡速度を制御するた め, 加熱発泡工程に拉いてインキ皮膜の発泡が部分的に 抑制され凹凸模様が形成される。

\section{8. 香料 インキ}

最近の印刷物は色彩も豊富ですばらしい。子供達に与 える絵本も頁をめくるとリンゴやバナナがおいしそらに 再現されている。印刷インキの本来の作用は視覚に訴兄 ることだが，仮に絵本のリンゴからリンゴの香りが発生 し臭覚にも訴えることができたら何んと素晴しいことで あろら。これを可能にしたのが香料インキである。

現在, 香料インキには二種類のインキがある。

\section{1 香料を直接添加したインキ}

このインキで印刷された絵柄から香料が揮発し芳香が 感じられる。使用される香料がインキビヒクルと相溶す 
れば容易にインキ化することができるが，香料が揮発性 のため比較的短い時間で印刷物から香りが失われる欠点 がある。

\section{2 カプセル化した香料を含有したインキ}

着色インキあるいはニスにカプセルを分散し印刷を行 ら。印刷はスクリーン方式が一般的である。印刷された 絵柄をこするとカプセルが破れて香気が発散する仕組で ある。この方法だとカプセルによって香料の揮発が抑兄 られているので比較的長時間の保存が確保されるが，印 刷されたままでは香料の揮発がないので香料インキとし ての機能は果たしていない。従って印刷物に擦るなどカ プセルの破壊を促す注釈が必要となる。

\section{9. 蛍光インキ}

光または紫外線を吸収して熱を伴わずに発光する現象 を蛍光という。蛍光は照射刺激光より一般に 波長が 長 く, その発光は瞬時に起こる。な敃刺激を止めた後も発 光が続く場合、これをりン光と呼んでいる。

商業印刷に使用される蛍光インキには蛍光染料をベン ゾグアナミン, メラミン，尿素樹脂などに溶かし込んで 粉末化した顔料が使用されている。蛍光顔料はその染料 が持つ反射特性に光刺激による蛍光成分が加算され, 鮮 明で強力な色彩効果を得ることができるので各種版式の インキが実用化され，ポスター,ディスプレー, パッヶ ージ，雑誌の表紙などに多用されている。

蛍光インキは偽造变造防止用インキとしてる利用され ている。紫外線を照射すると発光するものである。

\section{0. 金 インキ}

印刷物に金属光沢を与学るインキで顔料として脂肪酸 などで表面処理された細い䇴状のブロンズ粉が使われ る。このブロンズ粉は銅と亜鉛の合金で銅の含有率が多 くなると, 赤味の金色に逆に亜鉛の比率が増すと青味の 金色を呈する。ブロンズ粉は表面処理が施されている が，酸化されやすいため使用するインキのビヒクルには 酸化性の少ないものが使われ，また使用に際しては紙の 酸性度, 湿し水の $\mathrm{pH}$ にも注意を要する。市販の金イン キは赤ロおよび青口の色相の二種類が一般的で, 単独あ るいは混合して使用される。

なお，ブロンズ粉は空気中で酸化され緑青（塩基性炭 酸銅）を発生する可能性があるので, 銀インキと透明黄 インキを混ぜて作った金インキがある。金属光沢の面で は幾分劣るが食品包装材料の印刷に利用されている。

\section{1. 銀 インキ}

細い䇴状のアルミ粉を使用したインキで，アルミ粉の 形態は粉末状のものと有機溶剤で湿潤させたペースト状 のものがある。また表面処理の違いによりリーフィング とノンリーフィングの二種類に分けられ，前者を使用し たインキで印刷するとアルミ粉が被印刷体上に木の葉を 敷きつめたよらに層状にならび高い金属光沢を示す。こ れに反して後者を使用した場合，アルミ粉はインキ皮膜 中に不規則に分散し，金属光沢の点はリーフィングタイ プに劣るがメタリック調の外観を示す。使用される金属 粉の粒子径は印刷方式により異なり, オフセットインキ には 3〜 5 $\mu \mathrm{m}$ ，グラビフインキには 10〜 $15 \mu \mathrm{m}$ のもの が主体的に使われ，粒子径が大きくなるに従い金属光沢 に優れる。

また，銀インキと他の色インキと混合することにより シルバートーンとかパールトーンと呼ばれる金属光沢を 持った色インキが作られる。

\section{2. パールインキ}

パールインキはパール顔料をビヒクルル分散させたも の, あるいは透明着色インキにパール顔料もしくはアル ミ粉を混合してつくられる。

真珠光沢とは艶消しの銀表面に似た半光沢の感覚で表 面に薄膜の色に似た干渉色が浮いて見えるものである。 この柔らかな虹彩を件った真珠光沢は, 透明薄膜積層体 における光の多重反射現象によって起る。インキに使用 されるパール顔料は微粉化した天然雲母を酸化チタンで コーティングした物理的に安定な無機系顔料であり, 光 学的性質が通常の顔料と異なり規則的多重反射により真 珠光沢を与兄る特殊な色材である。

パールインキはオフセット，グラビア，スクリーン印 刷方式により印刷されて怙り, 包装紙, 化粧紙などに用 いられている。

\section{3. 示温インキ}

示温インキは温度の変化を色の变化としてとらえよう とするもので, 温度が上ると色が変化し温度が下っても 色が元にもどらない不可逆タイプと, 温度が元にもどる と復色する可逆タイプに分けられる。

示温材料の変色原理としては, 結晶転移, 熱分解, 固 相反応, 電子供与体・受容体の特定ふん囲気中での電子 授受, 結晶構造の変化に伴う光学的变化などによる。

今日, 可逆性示温インキで実用化されているものに, コレスティック液晶, 金属錯塩, メタモカラーの三種類 
がある。

\section{1 液晶インキ}

液㿟にはコレスティック液晶, ネマティック液晶, ス メティック液晶があり, 印刷インキにはコレスティック 液晶が応用されている。この種の液晶は板状構造をもち 光学的活性を示す分子で，その配列はらせん状態を示 す。コレスティック液晶に白色光を照射すると,らせん のピッチが可視光スペクトルのある波長に等しい時その 波長の光は選択的に強く散乱される。また, 温度の変化 により結晶構造が変化するのでらせんのピッチの変化に 従って散乱光の波長が移動し色が変化する。コレスティ ック液晶は化学的に不安定なためマイクロカプセル化し インキに使用される。印刷はスクリーン印刷あるいはグ ラビア方式によるューティングで行われる。

\section{2 金属錯塩}

無機系の $\mathrm{Ag}_{2} \mathrm{HgI}_{4}, \mathrm{Cu}_{2} \mathrm{HgI}_{4}$ などが実用化されてい る。耐光性に優れているので屋外用途に適している。

\section{3 メタモカラー}

パイロットインキの開発によるもので, 電子供与性呈 色化合物, 電子受容性化合物, アルコール類の三成分で 構成され，インキには 10〜15 $\mu \mathrm{m}$ の微小マイクロカプ セルにして使用される。

この発色機構は電子供与性呈色化合物と電子受容性化 合物がアルコール類の存在下で温度変化に応じて電子の 授受を行い，染料構造を取って発色し，またロイコ構造 を取って無色になるものと推定される。

\section{4. 経口医薬品用インキ}

医薬用カプセルあるいは錠剤に医薬メーカーのマーダ や医薬品名を表示するためのインキである。このインキ は医薬品とともに体内に摂取される関係上，インキに使 用さ机る材料は食用無害であることが必要である。

イタキの着色剤は医薬品用タール色素とそのアルミニ ウムレーキから選ばれ，ビヒクルには主にせルロース系 樹脂を水またはアルコールに溶解したものが使われる。

\section{5. 転写捺染インキ}

择染汇は直接择染法と転㝍捺染法がある。転写择染に

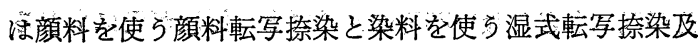
び乾式転写择染（昇華転㝍拪染）施あ。

\section{1 昇華転写挎染インキ}

このインキは主にポリェステれを主体とした繊維の择

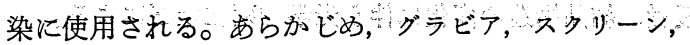
オフセット印刷方式により印刷された転写紙を布地に重 ね合わせて加熱口ールあるいは赤外線などによう加熱を
行う。昇華転写捺染インキには熱昇華性の分散染料が使 用されているので，加熱により染料が昇華しポリエステ ル繊維の分子間に定着される。従って, 後工程でのスチ 一ムによる染め込みや水洗が不要となる。

なお，この方式は捺染の分野に止らず感熱転写記録方 式としてカラープリンターなどュンピュータ端末機への 実用化が進められている。

\section{2 湿式転写捺染インキ}

この方法は木綿, 綟, 羊毛など天然繊維やナイロン, アクリル，ポリエステルなどの合成繊維に使用できる捺 染方式である。しかし，この方式は比較的加工工程が長 く経費が高く付くため現在では，ごく一部の天然繊維の 捺染に利用されているにすぎない。

転写ニスを引いた㔀離紙に印刷を行い転写紙を作成す る。この転写紙と布地を重ね合わせ絵柄を加熱転写した 後，スチームにより繊維への染め込みを行い，余分な染 料を水洗し捺染を完了する。使用される染料は分散染料 カチオン染料, 反応染料, 酸性染料の中から布地の素材 に適応したものが選ばれる。

\section{3 顔料転写捺染インキ}

このインキは塩ビ・酶ビ共重合体，エチレン・酢ビ共 重合体，ポリアミドなど熱可塑性樹脂とワックスをビヒ クルとし顔料が分散されたホットメルト型インキであ る。あらかじめ袔離紙にこのインキで印刷を行い転写紙 を作成する。この転写紙を布地と合わせ加熱圧着し転写 を行ら。

\section{6. 安全インキ}

小切手, 証券, 証紙類の偽造改ざん防止のために利用 されるインキである。

\section{1 色が退色するインキ}

ピヒタルにローダミンやオーラミンなどの塩基性染料 を使用したインキはインンク消しにより酸化されて消色す る。このインキで地影などを印刷しておくと文字を改ざ えした場合飞地紋が消えてしうので不正行為が明白と なる。

\section{2 変色するインキ}

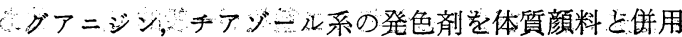
すると変色性のインキが得ら机る。ぬ芳香族西ミン類

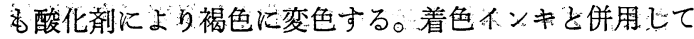
地紋などの印刷を行党ば薬剤により色が変色するので改 さん防止となる。

\section{3 その他}

蛍光インキまたは磁珄インキも偽造改ざん防止に利用 されている。 
蛍光インキは単独あるいは色インキと混合して文字な ぞを印刷する。蛍光染顔料は紫外線により特定の光を発 季るので，その真偽を検出することができる。

磁性インキも同様にこれらの目的に使用され磁気特性 を利用して検出を行う。

\section{7. ガラスインキ}

このインキは機能性インキといらょりはむしろ特殊イ キに分類される。セラミックカラーとかガラスエナメ ルなどと呼ばれ，䭪や硝子食器などの印刷に使用され る。印刷方式はスクリーン方式で常温で印刷を行らぺー スト型インキとスクリーンを加熱して印刷するホットメ ルトコールドセット型インキの二種類がある。

ペースト型インキは鉛ホウケイ酸ガラスの微粉末（フ ラックスまたはフリットという）と無機耐熱性顔料から なり, 稠度を整えるため必要量のスクィージオイルでぺ 一スト状に練り合わされている。印刷は一色印刷ごとに いったん $170^{\circ} \mathrm{C} \sim 190^{\circ} \mathrm{C}$ で乾燥し, 順次刷り重福後に $500^{\circ} \mathrm{C} \sim 600^{\circ} \mathrm{C}$ で焼付ける。

ホットメルト型インキはスクィージオイルに变えてワ ックス類が使用され，金属製のスクリーンに電流を通し タンキを加熱，流動性を与えて被印刷体に印刷を行う。 印刷の後, インキは直ちに固化するため刷り重䄈ができ 乾燥工程が省略できる。所定の印刷が終了したら焼付け 索行ら。

なお，インキの選択に当っては接着不良, 製品の変形 参どのトラブルを起こす可能性があるのでインキの特
性，印刷されるガラス製品の軟化点，膨脹係数などを十 分に考慮する必要がある。

\section{8. 終りに}

本報では比較的一般に知られている機能性インキにつ いて述べてきた。印刷物に要求される特殊機能も今日多 様化し全てを紹介することは無論出来ないが，印刷産業 界に和ける機能性インキの役割は大きく、今後, ますま すその重要性は高まるものと考える。

\section{参考文献}

印刷インキ工業会編: 印刷イソキハンドブック，(1978) 池田一郎 : 特殊印刷入門, (1983), 印刷学会出版部

シー・エム・シー編: 特殊機能インキ,ファインケミカ ルシリーズ, No.8 (1987)

相原, 一見, 根本編: 印刷イソキ技術, (1982), シー・ エム・シー

池森忠三郎 - 住谷光图編 : 特殊機能色素, (1986), シー ・エム・シー

蓮沼 宏: 光沢, (1960), コロナ社

工藤章次 : OCR の導入と活用, (1972), 日刊工業新聞 社

電子技術，Vol.26，No.7，(1984），日刊工業新聞社

電子技術，Vol.23，No.14，(1981），日刊工業新聞社 電子材料編集部編：プリント配線板技術，(1983), 工業 調查会

ペール顔料，メルク社技術資料

特開昭 54-155254

特公昭 59-1582

特公昭 61-23824 